\title{
Effects of Formaldehyde/Urea Mole Ratio, Panel Density, Shelling Ratio, and Waste Screen Dust on the Physical and Mechanical Properties, and Formaldehyde Emission of Particleboard Composite
}

\author{
Bünyamin Sarı ${ }^{1}$, Gökay Nemli ${ }^{1 *}$, Selahattin Bardak ${ }^{1}$, Mehmet Baharoğlu ${ }^{1}$, and Emir Zekoviç ${ }^{2}$ \\ 'Karadeniz Technical University, Faculty of Forestry, Trabzon-Turkey \\ ${ }^{2}$ Starwood Forest Products Company, Bursa-Turkey
}

(Received June 9, 2010)

\begin{abstract}
In this study, a detailed account is given of how urea formaldehyde adhesives with different mole ratios, panel density, shelling ratio and waste screen dust addition influence the physical and mechanical properties, and formaldehyde emission of particleboard panels. The experimental results showed that formaldehyde emission decreased with decreasing formaldehyde/urea mole ratio and shelling ratio, and waste screen dust addition. The modulus of rupture, modulus of elasticity and internal bond strength and thickness swelling of the test panels improved with increasing mole ratio, panel density and shelling ratio, and waste screen dust addition. However, increasing panel density negatively affected formaldehyde emission.
\end{abstract}

Keywords: particleboard, density, mole ratio, shelling ratio, waste screen dust, physical property, mechanical properties, formaldehyde emission.

\footnotetext{
"Corresponding author (Prof. Dr. Gökay Nemli), Tel: +90 462 3772868, Fax: +90 4623257499 , E-mail: nemli@ktu.edu.tr
}

\section{INTRODUCTION}

Particleboard is an engineered wood based panel composite consisting of wood particles of various sizes that are bonded together with a synthetic resin under heat and pressure. It is used widely in the manufacture of cabinets, furniture, home constructions, floor underlayment, wall, ceiling, paneling, mobile home decking, shelving, door core, kitchen cabinets, stair treats, mouldings and counter tops $/ 1 /$.

The demand for particleboard composite has recently increased throughout the world. This increase can be attributed to the economic advantage of low-cost wood, other lignocelluloses fibrous materials and inexpensive adhesive used for particleboard manufacturing $/ 2,3 /$.

Many researchers have investigated the effects of some manufacturing factors on the quality properties of particleboard: wood species $/ 4-5 /$, acidity of the wood particles $/ 6 /$, bark addition $/ 7,8 /$, permeability of wood $19 /$, type and amount of adhesive $/ 10 /$, dimensions of the particles $/ 11,12 /$, panel density $/ 13 /$, moisture content of particleboard $/ 14 /$, density profile $/ 15 /$ and pressing conditions $/ 16 /$.

Urea formaldehyde has been the major adhesive for particleboard composite manufacturing due to its low cost, short press time, lack of color in the finished product, excellent adhesion to lignocellulosics and 
intrinsic cohesion, high reactivity and water solubility. However, it has high reversibility of the aminomethylene link, which also explains the low resistance of urea formaldehyde resins against the influence of water and moisture, especially at higher temperature. This is one of the reasons for its formaldehyde emission, when hardened and in service 117,18 . Air pollution in buildings has become a matter of increasing concern. Pollutants such as formaldehyde are emitted into indoor air from the construction products and building materials. The formaldehyde causes health problems such as asthma and cancer /19$21 \%$

The purpose of this study was to evaluate the effects of formaldehyde/urea mole ratio of the adhesive, panel density, shelling ratio, and addition of waste screen dust on the physical (thickness swelling) and mechanical (modulus of rupture, modulus of elasticity, internal bond strength) properties, and formaldehyde emission of particleboard bonded with urea formaldehyde adhesive.

\section{EXPERIMENTAL PROCEDURE}

\subsection{Panel Manufacturing}

Particleboard panels were manufactured in Starwood Forest Products Company, Turkey, using standardized procedures that simulated industrial production.
Industrial particles (furnish of a mixture of Pinus brutia Ten., Fagus orientalis L. and Quercus cerris L.) were used as raw materials for particleboard manufacturing. The wood of each species was processed into particleboard furnish by passing through a chipper and a ring flaker. The particles were dried to $1 \%$ moisture content. A screening machine with meshes of 1 and 0.25 $\mathrm{mm}$ aperture and a pneumatic system were used to remove undersized particles and to separate the core and surface layer particles. The screen dusts passed through $0.25 \mathrm{~mm}$ aperture were added to surface layer particles for the manufacturing of panel types $\mathrm{F}$ and $\mathrm{H}$ (Table 1). Dried particles were then blended with urea formaldehyde resin. Based on the oven dry particle weight $11 \%$ and $9 \%$ urea formaldehyde resin was applied for the surface and core layers, respectively. Ammonium sulphate and paraffin were used, respectively, as a hardener and hydrophobic substance for panel manufacturing. The mats were pressed in a hot press at temperature of $483 \mathrm{~K}$ using a pressure of $26 \mathrm{x}$ $10^{-4} \mathrm{~kg} / \mathrm{m}^{2}$ for $130 \mathrm{sec}$. The resulting panels were sanded with a sequence of 50-60-80-100 and 120 grit sand papers. The thickness of the panels was $18 \mathrm{~mm}$. A total of 16 experimental panels, two for each type of panel, were manufactured. All boards were conditioned in a chamber with a temperature of $293 \mathrm{~K}$ and a relative humidity of $65 \%$ before further experiments were carried out. The experimental design of this study is illustrated in Table 1.

Table 1

Experimental design of the study

\begin{tabular}{|c|c|c|c|c|}
\hline Panel Type & $\begin{array}{c}\text { Formaldehyde/Urea } \\
\text { Mole Ratio }\end{array}$ & $\begin{array}{c}\text { Panel Density } \\
\left(\mathrm{Mg} / \mathrm{m}^{3}\right)\end{array}$ & $\begin{array}{c}\text { Shelling } \\
\text { Ratio (\%) }\end{array}$ & $\begin{array}{c}\text { Waste } \\
\text { Screen Dust } \\
\text { Addition (\%) }\end{array}$ \\
\hline A & 1.09 & 0.65 & 30 & 0 \\
\hline B & 1.09 & 0.75 & 30 & 0 \\
\hline C & 1.20 & 0.65 & 30 & 0 \\
\hline D & 1.20 & 0.75 & 30 & 0 \\
\hline E & 1.09 & 0.65 & 40 & 0 \\
\hline F & 1.09 & 0.65 & 40 & 15 \\
\hline G & 1.20 & 0.65 & 40 & 0 \\
\hline H & 1.20 & 0.65 & 40 & 15 \\
\hline
\end{tabular}

SR: Shelling ratio (The ratio of the face thickness to the total thickness) 


\subsection{Mechanical and Physical Testing}

Test samples were cut from the boards and the following properties were determined in accordance with appropriate European Norms (EN): modulus of rupture (MOR) and modulus of elasticity (MOE) (EN 310), internal bond strength (IB) (EN 319) and thickness swelling (TS) (EN 317) /22-24/.

Twenty samples, $50 \mathrm{~mm} \times 50 \mathrm{~mm} \times 18 \mathrm{~mm}$, from each type of panel were used for the TS property. Samples were submerged in distilled water for $24 \mathrm{~h}$ immersion before thickness measurements. The sample thickness was determined by taking a measurement at a specific location, the diagonal cross point, on the sample. After $24 \mathrm{~h}$ immersion, samples were drip-dried, wiped clean on any surface water.

A total of 20 samples with dimensions of $400 \mathrm{~mm} \mathrm{x}$ $50 \mathrm{~mm} \times 18 \mathrm{~mm}, 10$ parallel and 10 perpendicular to the sanding direction of the panels, were tested for each panel type to determine MOR and MOE.

Twenty samples, $50 \mathrm{~mm} \times 50 \mathrm{~mm} \times 18 \mathrm{~mm}$, from each type of panel were used for the determination of IB strength. The load was continuously applied to the samples throughout the tests at a uniform crosshead speed of $1.0 \mathrm{~mm} / \mathrm{min}$ until failure occurs.

\subsection{Determination of Formaldehyde Emission}

Three samples $(20 \mathrm{~mm} \times 20 \mathrm{~mm} \times 18 \mathrm{~mm})$ were randomly taken from each type of panel for formaldehyde emission (FE) determination using the perforator method based on EN $120-1$ standard /25/. The perforator test involves reflux in boiling toluene with approximately $110 \mathrm{~g}$ of small cube samples. The reflux speed of the system was adjusted to $30 \mathrm{~mL} / \mathrm{min}$, and the extraction was conducted for $2 \mathrm{~h}$. The extracted formaldehyde was collected in water, which was then added with $50 \mathrm{ml}$ of iodine solution and $20 \mathrm{ml}$ of sodium hydroxide in a dark room for $15 \mathrm{~min}$. A $10 \mathrm{~mL}$ mixture of sulfuric cid and sodium thiosulphate solution was applied to the mixture until its color changes from light brown to light yellow $/ 26 /$.

\subsection{Statistical Analysis}

The effects of formaldehyde/urea mole ratio, panel density, shelling ratio and waste screen dust addition on the properties of particleboard were evaluated by statistical analysis. The analysis of variance (ANOVA) and $t$ - test were performed to detect if there were significant differences between the mean values of the properties of the various board types. When a significant difference among factors and levels was indicated, the Newman-Keuls test was performed for comparisons of means to identify which groups were significantly different from others at $95 \%$ confidence level.

\section{RESULTS AND DISCUSSION}

Table 2 displays the results of physical and mechanical properties and formaldehyde emission of boards made in the various formulations. Table 3 summarizes the statistical analysis results of the various comparisons undertaken.

Based on the TS EN 312 (2005) standard, 11.5 and 13.0, are the minimum requirements for MOR of particleboard panels for general uses and interior fitments (including furniture), respectively $127 /$, while the minimum MOE for interior fitments is $1600 \mathrm{~N} / \mathrm{mm}^{2}$. Panel types B, D and $\mathrm{H}$ had higher MOR and MOE for the general purposes and furniture manufacturing requirements.

IB data ranged from 0.184 to $0.456 \mathrm{~N} / \mathrm{mm}^{2}$. The minimal requirement of internal bond strength for general purpose and furniture manufacturing are 0.24 and $0.35 \mathrm{~N} / \mathrm{mm}^{2}$, respectively. According to the test results, $\mathrm{B}, \mathrm{D}$ and $\mathrm{H}$ type panels were higher than the TS EN requirements.

A maximum TS value of $15 \%$ is allowed for particleboard panels used in load-bearing applications in dry conditions $127 \%$. Average TS values of the test panels ranged from 14.87 to $21.19 \%$. The results showed that panel types $\mathrm{B}, \mathrm{D}$ and $\mathrm{H}$ had the required level of TS for load bearing applications in dry conditions.

The maximum permissible formaldehyde content for El quality is $8 \mathrm{mg} \mathrm{CHOH} / 100 \mathrm{~g}$ dry sample $125 /$. The results showed that, the value of mole ratio for the El limit was 1.09 . How mole ratio of the adhesive, panel density, shelling ratio, and waste screen dust addition influenced the properties of particleboard panels is presented in Figures 1-5. 
Table 2

Results of physical and mechanical properties and formaldehyde emission of the test panels

\begin{tabular}{|c|c|c|c|c|c|}
\hline $\begin{array}{c}\text { Panel } \\
\text { Type }\end{array}$ & $\begin{array}{c}\text { MOR } \\
\left(\mathrm{N} / \mathrm{mm}^{2}\right)\end{array}$ & $\begin{array}{c}\text { MOE } \\
\left(\mathrm{N} / \mathrm{mm}^{2}\right)\end{array}$ & $\begin{array}{c}\text { IB } \\
\left(\mathrm{N} / \mathrm{mm}^{2}\right)\end{array}$ & $\begin{array}{c}\text { TS } \\
(\%)\end{array}$ & $\begin{array}{c}\text { FE } \\
(\mathrm{mg} \mathrm{CHOH} / 100 \mathrm{~g} \text { dry sample) }\end{array}$ \\
\hline A & 9.03 & 1229.98 & 0.184 & 21.19 & 6.52 \\
\hline B & 13.39 & 1845.86 & 0.389 & 14.92 & 7.24 \\
\hline C & 10.78 & 1442.62 & 0.233 & 18.45 & 13.88 \\
\hline D & 14.45 & 2187.74 & 0.456 & 14.28 & 15.45 \\
\hline E & 10.22 & 1401.43 & 0.228 & 19.24 & 7.06 \\
\hline F & 12.57 & 1559.07 & 0.341 & 16.45 & 6.71 \\
\hline G & 12.10 & 1513.35 & 0.335 & 17.01 & 14.63 \\
\hline H & 13.88 & 2004.51 & 0.412 & 14.87 & 14.09 \\
\hline
\end{tabular}

Table 3

Comparison of mean value of all tested properties of board types

\begin{tabular}{|c|c|c|c|c|}
\hline Property & MR & PD $\left(\mathrm{g} / \mathrm{cm}^{3}\right)$ & SR (\%) & WSDA (\%) \\
\hline MOR & $1.09: 11.30(\mathrm{a})$ & $0.65: 9.90(\mathrm{a})$ & $30: 9.90(\mathrm{a})$ & $0: 11.16(\mathrm{a})$ \\
& $1.20: 12.79(\mathrm{~b})$ & $0.75: 13.92(\mathrm{~b})$ & $40: 11.16(\mathrm{~b})$ & $15: 13.20(\mathrm{~b})$ \\
\hline MOE & $1.09: 1508.83(\mathrm{a})$ & $0.65: 1336.30(\mathrm{a})$ & $30: 1336.30(\mathrm{a})$ & $0: 1457.39$ (a) \\
& $1.20: 1787.05(\mathrm{~b})$ & $0.75: 2016.80(\mathrm{~b})$ & $40: 1457.39(\mathrm{~b})$ & $15: 1781.29(\mathrm{~b})$ \\
\hline IB & $1.09: 0.285(\mathrm{a})$ & $0.65: 0.208(\mathrm{a})$ & $30: 0.208(\mathrm{a})$ & $0: 0.281$ (a) \\
& $1.20: 0.359(\mathrm{~b})$ & $0.75: 0.422(\mathrm{~b})$ & $40: 0.281(\mathrm{~b})$ & $15: 0.376(\mathrm{~b})$ \\
\hline TS & $1.09: 17.95(\mathrm{a})$ & $0.65: 19.82(\mathrm{a})$ & $30: 19.82(\mathrm{a})$ & $0: 18.12(\mathrm{a})$ \\
& $1.20: 16.15(\mathrm{~b})$ & $0.75: 14.60(\mathrm{~b})$ & $40: 18.12(\mathrm{~b})$ & $15: 15.64(\mathrm{~b})$ \\
\hline FE & $6.88(\mathrm{a})$ & $0.65: 10.20(\mathrm{a})$ & $30: 10.20(\mathrm{a})$ & $0: 10.84(\mathrm{a})$ \\
& $14.51(\mathrm{~b})$ & $0.75: 11.34(\mathrm{~b})$ & $40: 10.84(\mathrm{~b})$ & $15: 10.40(\mathrm{~b})$ \\
\hline
\end{tabular}

MR: Mole Ratio, PD: Panel Density, SR: Shelling Ratio, WSDA: Waste Screen Dust Addition, Values (a, b) having the different letter are significantly different at $95 \%$ confidence level.

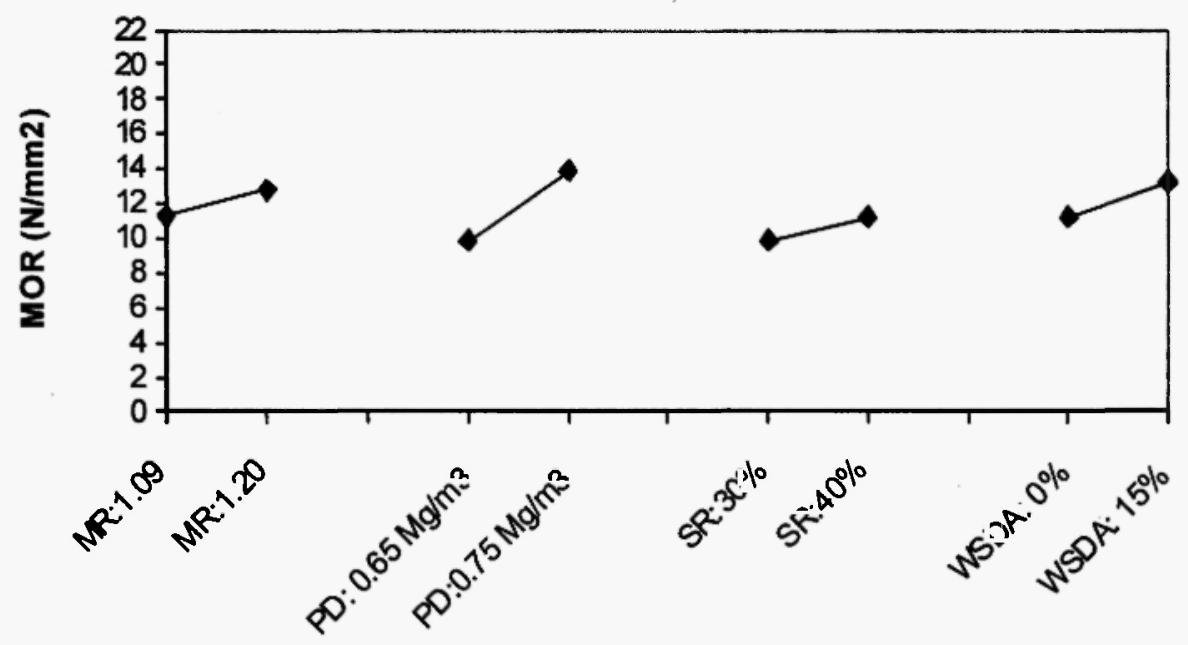

Fig. 1: Effects of some manufacturing factors on the MOR. 


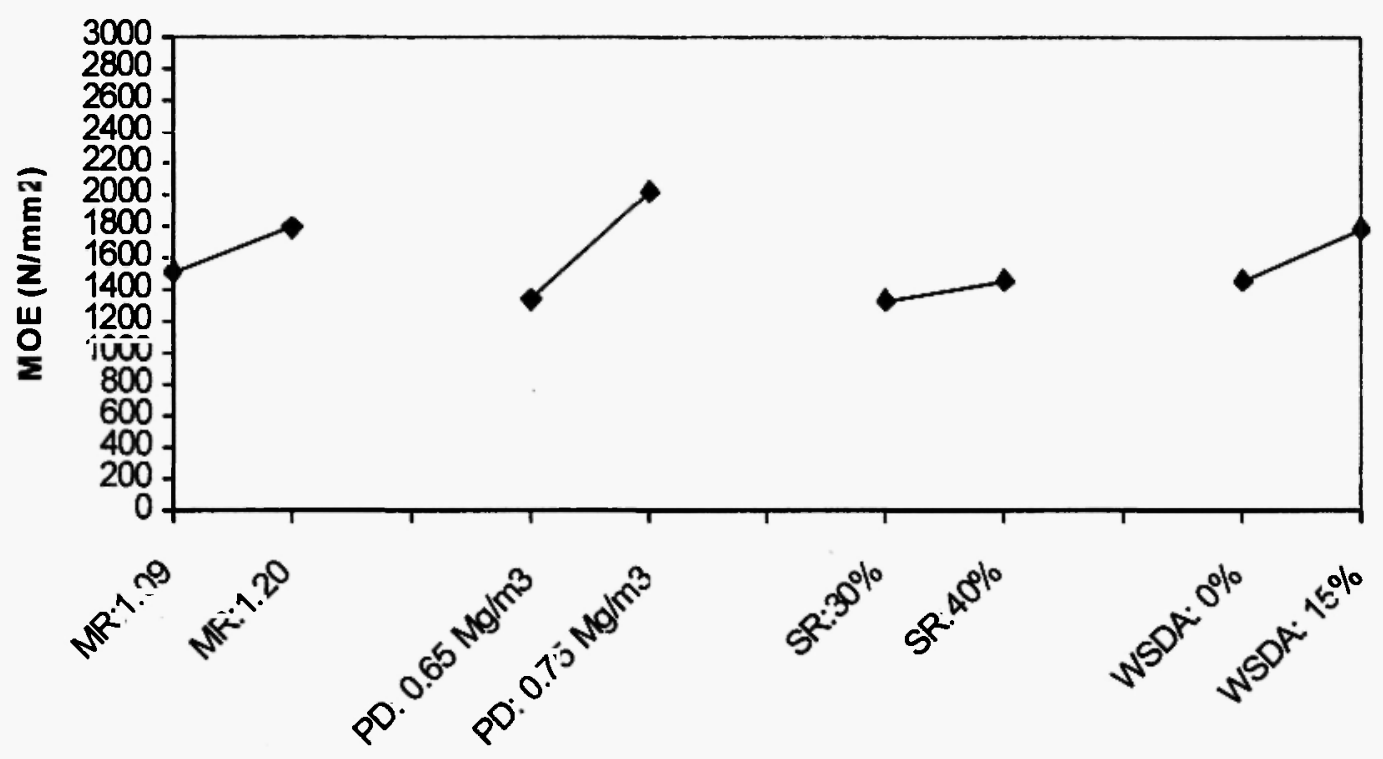

Fig. 2: Effects of some manufacturing factors on the MOE.

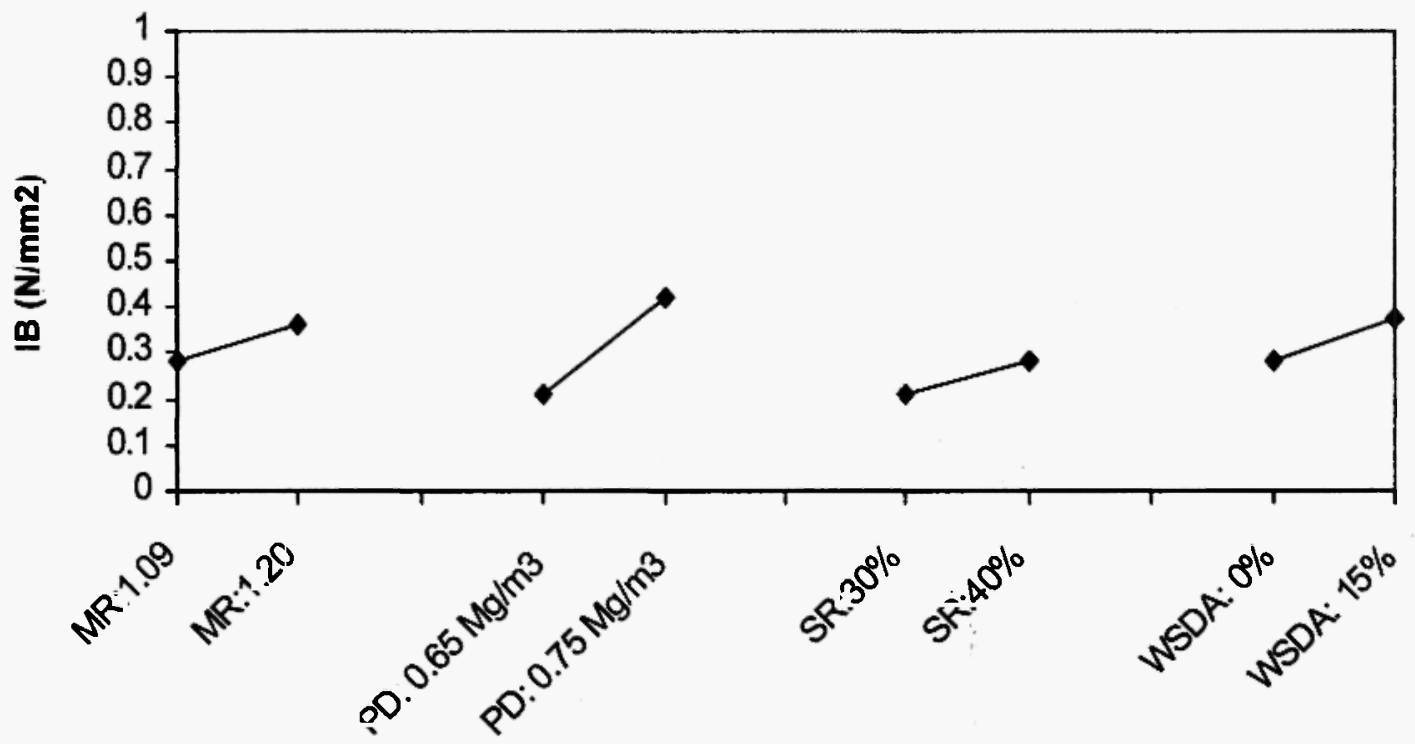

Fig. 3: Effects of some manufacturing factors on the IB. 


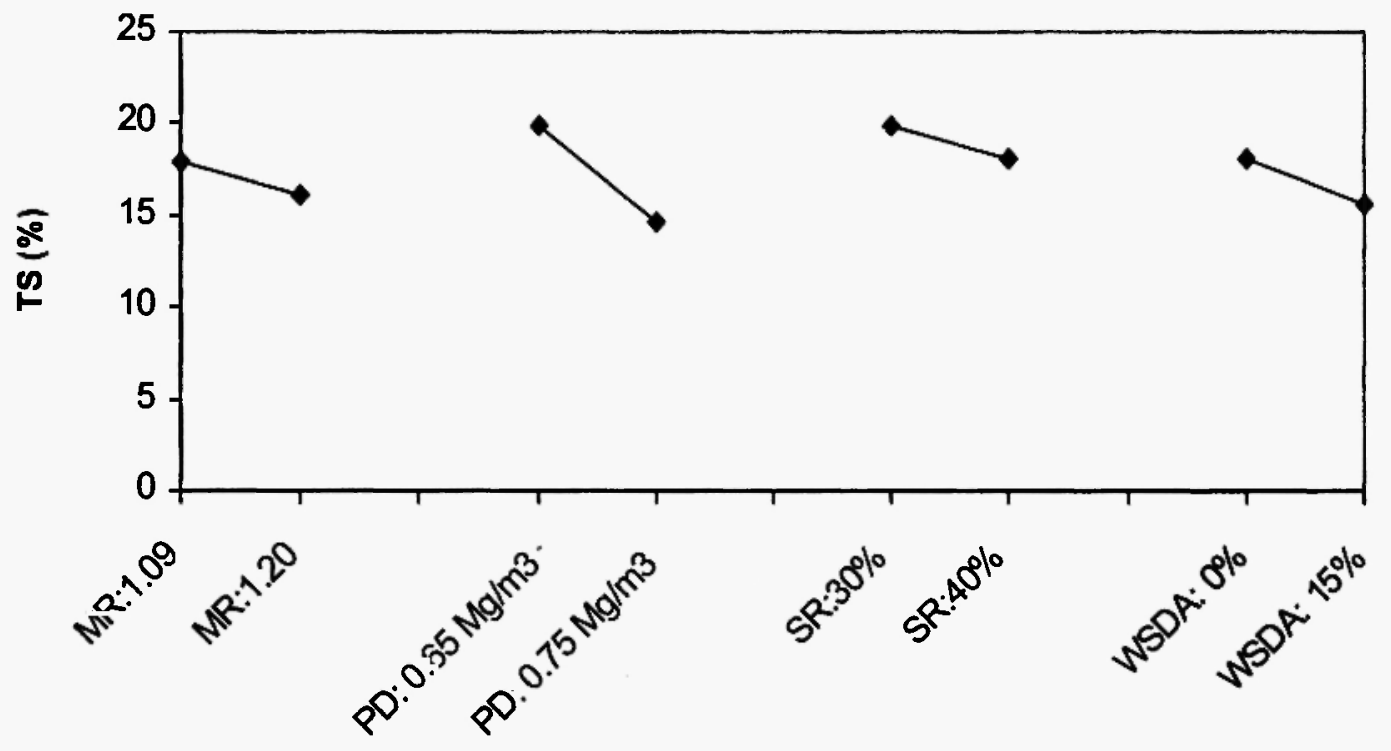

Fig. 4: Effects of some manufacturing factors on the TS.

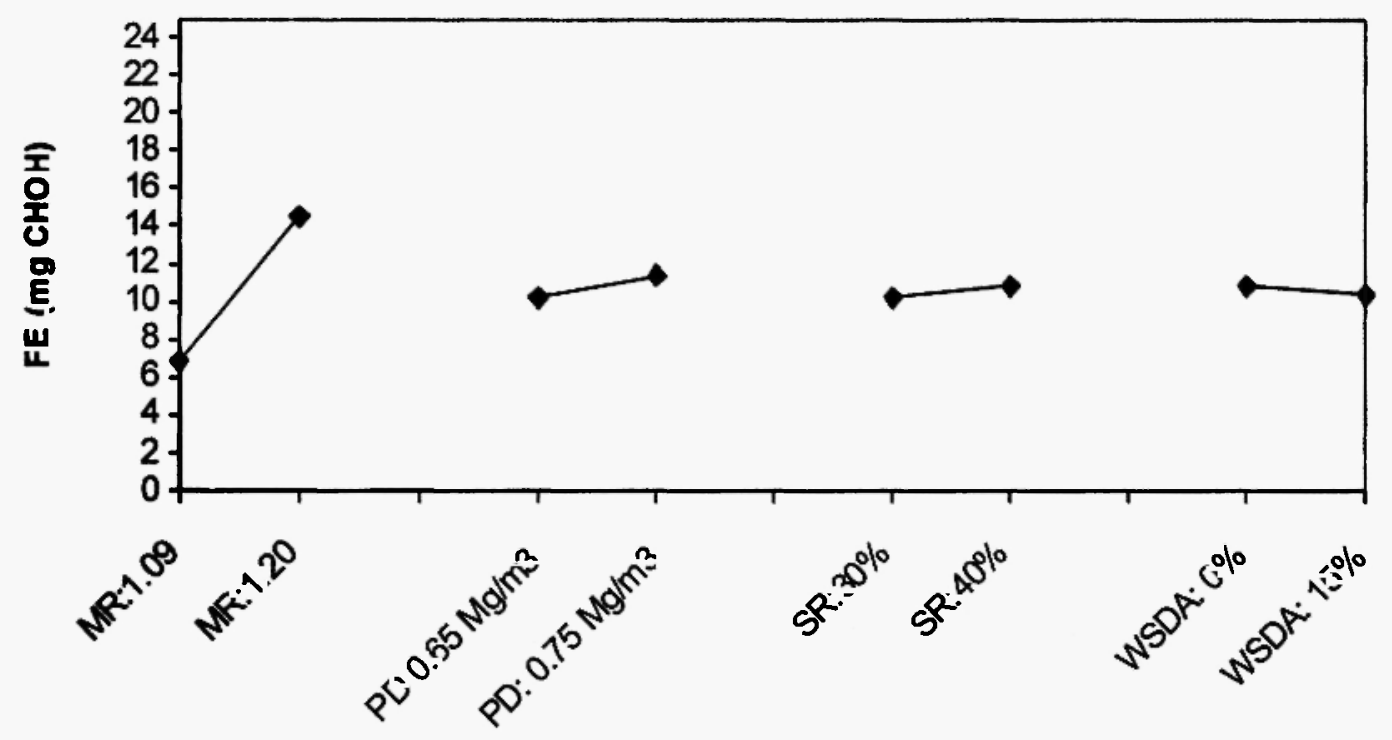

Fig. 5: Effects of some manufacturing factors on the FE.

\subsection{Effect of Formaldehyde/Urea Mole Ratio}

MOR, MOE, IB and TS values improved with increasing formaldehyde/urea mole ratio from 1.09 to 1.20. The main differences between the panels produced with urea formaldehyde resins with high and low contents of formaldehyde are due to their reactivity as a consequence of the different free formaldehyde content and their degree of crosslinking in the cured network. The increased reactivity and crosslinking of the adhesive, and the rate of hardening in adhesives of higher formaldehyde/urea mole ratio causes tighter and more compact board structure. For this reason, mechanical properties increase and thickness swelling decreases due to high degree of crosslinking and diffusion of the water into the particleboard is restricted 
128\%. Dunky (1998) stated that there are no ether bridges, no unreacted branch-site methylol groups and no other free formaldehyde in the adhesive at low formaldehyde / urea mole ratio /18/.

Increasing the formaldehyde/urea mole ratio negatively affected the formaldehyde emission of the test panels. This is due to the higher content of free formaldehyde in adhesive. This was demonstrated previously by several researchers $/ 29-31 /$.

\subsection{Effect of Panel Density}

Increasing panel density from 0.65 to $0.75 \mathrm{Mg} / \mathrm{m}^{3}$ significantly improved the MOR, MOE, IB and TS of the particleboard composite. This expected finding is attributable to the more compact and tighter structure of particleboard at high density. A particleboard structure that is more compact and tighter is accompanied by increased mechanical properties, but decreased water diffusion 132-34/. However, FE values of the panels increased with increasing panel density. Differences in the FE are mainly due to adhesive content of the particleboard panels. Panels at high density consist of high amount of wood material. The adhesive is used based on the weight of the particles. For this reason, particleboard panels at $0.75 \mathrm{Mg} / \mathrm{m}^{3}$ density consist of higher amount of adhesive compared to panels at 0.65 $\mathrm{Mg} / \mathrm{m}^{3}$ density. Increasing adhesive in the particleboard negatively affects the formaldehyde emission $/ 35 /$.

\subsection{Effect of Shelling Ratio}

Increasing shelling ratio from 30 to $40 \%$ positively affected the physical and mechanical properties of the test panels. This may be attributable to high amount of fine particle in the surface layer. Increasing the amount of surface layers causes tighter and more compact structure on the particleboard surfaces. This tighter and compact structure increases the heat transfer to the core layer of particleboard. These incidences improve the bending and bonding properties, and make it difficult for water to diffuse into the particleboard $/ 36 /$. The results showed that increasing shelling ratio negatively affected the formaldehyde emission of particleboard. At a higher shelling ratio, the amount of adhesive higher for surface layer particles compared to the core particles. In addition, the tighter and more compact structure on the surface of particleboard prevents formaldehyde releasing during hot pressing. For this reason, an increased amount of formaldehyde stays in the particleboard. Particleboards produced with a low shelling ratio have slack and porous structure. A particleboard wit a slack and porous structure exhibits increased formaldehyde release during hot pressing. For these reasons, formaldehyde emission is lower for panels containing a low amount of surface particles $/ 37 /$.

\subsection{Effect of Waste Screen Dust Addition}

Waste screen dust addition improved all tested properties of particleboard panels. Particleboard has a porous and slack structure. The dust fills pores between wood particles. Contacts and adhesion between the blended particles increase due to the filling of pores. Increased adhesion improves the mechanical properties of particleboard. Dusts have a low amount of woody cells due to their small dimensions. They absorb less water than wood particles. Filling of pores between wood particles increases the conductivity of hest into the core layer of particleboard. A higher temperature in the core layer during hot-pressing improves adhesive curing and hence also the internal bond strength and decreases the formaldehyde emission /38-40/.

\section{CONCLUSION}

Based on the results of this study, the following conclusions were obtained:

1. Increasing panel density improved the physical and mechanical properties. However, panel density negatively affected the formaldehyde emission.

2. While decreasing formaldehyde/urea mole ratio positively affected the formaldehyde emission, panels manufactured with urea formaldehyde adhesive at low mole ratio had poorer physical and mechanical properties.

3. Waste screen dust addition improved all tested properties of the particleboard panels.

4. Shelling ratio was found to affect properties of particleboard. Increasing the shelling ratio caused better physical and physical properties. However, 
this application increased the formaldehyde emission.

5. Panel types $B$ and $F$ had the required levels of formaldehyde emission (grade $E_{1}$ ) and mechanical properties for general uses at indoor applications. Panel type B also can be used for furniture applications.

\section{REFERENCES}

1. Anonymous, National Particleboard Association, MD 20879, Gaithersburg (1993).

2. T. Sellers, Wood Technology, 127: 40-43 (2000).

3. A. Nourbakhsh, Journal of Reinforced Plastics and Composites, 29: 481-489 (2010).

4.D.P. Kamden and S.T. Sean, Forest Products Journal, 22: 65-68 (1984).

5.C.G. Carl, Forest Products Journal, 44: 26-32 (1994).

6. K.C. Akyuz, G. Nemli, M. Baharoğlu and E. Zekoviç, International Journal of Adhesion and Adhesives, 30: 166-169 (2010).

7. G. Nemli, H. Kırcı and A. Temiz, Industrial Crops and Products, 20: 339-344 (2004).

8. G. Nemli, E.D. Gezer, S. Yıldız, A. Temiz and A. Aydın, Bioresource Technology, 97: 2059-2064 (2006).

9. F.C. Lynam, In: L. Mitlin, Pressmedia Books Ltd, UK (1969).

10. W.F. Lehman, Forest Products Journal, 20: 48-54 (1970).

11. H.A. May, Holz als Roh-und Werkstoff, 41: 271-275 (1983).

12. K.C. Au and R.O. Gertjejansen, Forest Products Journal, 39: 47-50 (1989).

13. T. Maloney, Miller Freemen Pub., San Francisco/California (1977).

14. Y. Dexin and A.L. Ostman, Holz als Roh-und Werkstoff, 44: 281-286 (1983).

15. G. Nemli and S. Demirel, Journal of Composite Materials, 41: 1793-1802 (2007).

16. O. Suchsland, Forest Products Journal, 17: 51-57 (1967).

17. B. Li, Y. Zheng, Z. Pan and B. Hartsough, Industrial Crops and Products, 30: 65-71 (2009).
18. M. Dunky, International Journal of Adhesion and Adhesives, 18: 95-107 (1998).

19. S. Uchiyama, E. Matsushima, N. Kitao, H. Tokunaga, M. Ando and Y. Otsuba, Atmospheric Environment, 41: 8825-8830 (2007).

20. M. Aubier, Environmental Health Perspectives, 115: 210-214 (2007).

21. T.J. Kelly, D.L. Simith and J. Satole, Environment Science and Technology, 33: 81-88 (1999).

22. EN 310, ECS, Brussels (1993).

23. EN 317, ECS, Brussels (1993).

24. EN 319, ECS, Brussels (1993).

25. EN 120-1, ECS, Brussels (1993).

26. N. Ayrılmıs, U. Büyüksarı, E. Avcı and E. Koç, Forest Ecology and Management, 259: 65-70 (2009).

27. TS EN 312, Turkish Standards Institute, Ankara (2005) (in Turkish).

28. S. Nieh and T. Sellers, Forest Products Journal, 41: 49-53 (1991).

29. G.E. Myers, Forest Products Journal, 33: 27-37 (1981).

30. B. Meyer, Journal of the Air Pollution Control Association, 35: 816-821 (1985).

31. A.T. Go, In: T. Maloney, Proceedings of 25th International Particleboard/Composite Materials Symposium, W.S.U., Washington (1991).

32. F.D. Larmore, Forest Products Journal, 9: 131-134 (1959).

33. C.J. Gatchell, B.G. Heebink and F.W. Hefty, Forest Products Journal, 16: 46.59 (1966).

34. B.R. Vital, J.B. Wilson and P.H. Kanarek, Forest Products Journal, 30: 23-29 (1980).

35. G. Nemli and I. Ozturk, Building and Environment, 41: 770-774 (2006).

36. G. Nemli, Turkish Journal of Agriculture and Forestry, 27: 99-104 (2003).

37. T. Akbulut, Istanbul University, Istanbul, Turkey (in Turkish) (1995).

38. J. Brumbaugh, Forest Products Journal, 10: 3-42 (1960).

39. G. Nemli and G. Çolakoglu, Building and Environment, 40: 83-87 (2005).

40. G. Nemli, I. Aydın and E. Zekoviç, Materials and Design, 28: 1169-1176 (2007). 